\title{
Autentikasi Centella asiatica (L.) Urb. (Pegagan) dan Adulterannya Berdasarkan Karakter Makroskopis, Mikroskopis, dan Profil Kimia
}

\author{
Authentication of Centella asiatica (L.) Urb. (Pegagan) and Its Adulterant Based on \\ Macroscopic, Microscopic, and Chemical Profiling
}

\author{
Anshary Maruzy,"Mery Budiarti, Dyah Subositi \\ Balai Besar Litbang Tanaman Obat dan Obat Tradisional, \\ Badan Litbang Kesehatan, Kemenkes RI, Tawangmangu, Indonesia \\ *E-mail: un_sorry03@yahoo.com
}

Diterima: 21 Mei 2019

Direvisi: 25 September 2019

Disetujui: 24 Januari 2020

\begin{abstract}
Abstrak
Pegagan atau Centella asiatica (L.) Urb. secara empiris digunakan sebagai tanaman obat dan secara ilmiah dapat digunakan sebagai antihipertensi berdasarkan hasil Saintifikasi Jamu. Pemanfaatan dan permintaan simplisia $C$. Asiatica sebag ai bahan baku jamu tanpa diikuti dengan upaya budidaya dapat membuka peluang pemalsuan atau penggunaan jenis tumbuhan yang salah. Hydrocotyle verticillata dan Merremia emarginata termasuk alternatif tumbuhan yang dapat dimanfaatkan sebagai pemalsu simplisia $C$. asiatica. Fokus penelitian ini adalah studi perbandingan karakter makroskopis, mikroskopis dan profil senyawa kimia dari C. asiatica, $H$. verticillata, dan $M$. emarginata. Tahapan kegiatan pada penelitian ini meliputi pemilihan sampel secara purposive sampling, yaitu dari wilayah Jawa Barat (Bogor), Jawa Tengah (Tawangmangu) dan Jawa Timur (Malang), pengumpulan data karakter makroskopis dan mikroskopis, dilanjutkan dengan penentuan profil senyawa kimia dengan metode kromatografi lapis tipis serta kuantifikasi kandungan senyawa asiatikosida yang merupakan senyawa penanda spesies C. asiatica. Hasil penelitian menunjukkan bahwa karakter pembeda yang unik dan mudah secara makroskopis antara Centella asiatica dengan spesies potensi adulteran Hydrocotyle verticillata adalah bentuk daun, sedangkan $C$. asiatica dengan Merremia emarginata adalah karakter tipe munculnya daun. Karakter bentuk daun simplisia antara $C$. asiatica dan $H$. verticillata dapat dijadikan pembeda yang jelas. Karakter anatomi dan fragmen serbuk yang dapat dijadikan pembeda antara $C$. asiatica dan $H$. verticillata adalah keberadaan empulur pada tangkai dan stolon, tipe stomata, dan adanya trikom. Sedangkan profil senyawa kimia dan kuantitas senyawa asiatikosida dari ketiga spesies tersebut berbeda secara signifikan. Ketiga spesies tumbuhan tersebut dengan Kromatografi Lapis Tipis (KLT) memiliki jumlah spot yang berbeda dan senyawa asiatikosida hanya dapat dideteksi dari simplisia $C$. asiatica.
\end{abstract}

Kata kunci: Autentikasi; Pegagan; Adulteran

\begin{abstract}
Pegagan or Centella asiatica (L.) Urb. empirically used as medicinal plant and scientifically can be used as antihypertension based on the results of the Jamu Saintification. Raw materials from C. asiatica have the potential to occur adulteration or incorrect use of plants species. There are two species of plants that have the potential to become adulterants of $C$. asiatica, namely Hydrocotyle verticillata and Merremia emarginata. Thus, the purpose of this study is to authenticate from Pegagan by comparing the macroscopic, microscopic, and chemical profiles of $C$. asiatica, H. verticillata, and M. emarginata. The method of data collection is done by purposive sampling using form intruments to record macroscopic and microscopic characters, while the chemical profiles are tested using thin layer chromatography methods to determine the content of asiaticosides in both potential adulterants species. The research was conducted at three sampling points: Central Java (Tawangmangu), West Java (Bogor), and East Java (Malang), while for laboratory research activities carried out at B2P2TOOT, Tawangmangu. The results showed macroscopically unique and easy distinguishing characters between $C$. asiatica and potential adulterant species $H$. verticillata is a leaf shape, whereas $C$. asiatica with $M$. emarginata are leaf-type appearance characters. The character of the simplicia leaf shape between $C$. asiatica and $H$. verticillata can be a distinct differentiator characters. Anatomical characters and powder fragments that can be used as a differentiator characters between $C$. asiatica and $H$. verticillata are the presence of pith on the stalk and stolon, the type of stomata, and the presence of trichomes. Authentication of simplicia powder of $H$. verticillata as an adulterant potential of C. asiatica with TLC, can be easily known by the absence of asiaticosides in these simplicia so that $H$. verticillata cannot be a substitute species for C. asiatica.
\end{abstract}

Key words: Authentication; Centella asiatica; Adulterant 


\section{PENDAHULUAN}

Indonesia adalah negara yang memiliki keanekaragaman hayati yang sangat tinggi dan termasuk ke dalam wilayah Malesia. Wilayah Malesia (Indonesia, Malaysia, Filipina, dan New Guinea) memiliki $10 \%$ dari keseluruhan jumlah jenis tumbuhan berbunga di dunia. ${ }^{1}$ Indonesia merupakan negara dengan jumlah sekitar $80 \%$ tumbuhan obat dari jumlah total tumbuhan obat di dunia. $^{2}$

Indonesia memiliki lebih dari 45.000 jenis tumbuhan tingkat tinggi termasuk pakupakuan, atau sekitar 25.000 hingga 30.000 jenis tumbuhan berbunga di Indonesia. ${ }^{2,3}$ Selain itu, Pulau Jawa memiliki sekitar 4.600 jenis tumbuhan berbunga. ${ }^{1}$ Pulau Jawa memiliki jumlah suku tumbuhan sebanyak 238 suku tumbuhan. Salah satu suku tersebut adalah Apiaceae.

Centella asiatica (L.) Urb. atau pegagan merupakan tanaman yang termasuk ke dalam suku Umbelliferae atau Apiaceae. ${ }^{4} C$. asiatica terdistribusi di Asia Tenggara dan sebagian kawasan subtropis. ${ }^{5}$ Secara empiris telah banyak digunakan sebagai salah satu tanaman untuk bahan obat tradisional dalam kehidupan masyarakat di Indonesia. ${ }^{6-8}$ Selain itu, telah banyak produk-produk obat yang mengandung bahan dari $C$. asiatica di Indonesia.

Khasiat secara ilmiah dari $C$. asiatica telah banyak diteliti pada hewan coba dan menyimpulkan bahwa $C$. asiatica dapat digunakan sebagai antioksidan, antigastritis, antitumor, penyembuhan luka, imunomodulator, antiproliferasi, dan sebagainya. ${ }^{9-16}$ Selain itu, dalam hasil Saintifikasi Jamu disimpulkan bahwa $C$. asiatica merupakan salah satu komponen ramuan antihipertensi. ${ }^{17,18}$ Dalam usaha Saintifikasi Jamu dan menjaga kualitas bahan baku tumbuhan obat yang mengandung $C$. asiatica, ada beberapa tahapan yang harus dilakukan, salah satu yang terpenting adalah autentikasi dari bahan baku tumbuhan obat, secara makroskopis, mikroskopis, dan profil kimia.

Bahan baku dari $C$. asiatica berpotensi terjadi pemalsuan atau salah dalam penggunaan jenis tumbuhan. Potensi pemalsuan dan salah penggunaan tumbuhan obat dapat terjadi akibat dari persamaan nama daerah dan kesamaan morfologi vegetatif. $^{19}$ di Indonesia, tumbuhan Hydrocotyle verticillata merupakan tumbuhan yang sering diidentifikasi sebagai pegagan atau $C$. asiatica. Selain itu juga, Merremia emarginata merupakan tumbuhan lain yang berpotensi menjadi tumbuhan pemalsu dari C.asiatica. Berdasarkan penelitian Mansur nama daerah dari $M$. emarginata adalah pegagan utan dan memiliki morfologi yang sama dengan $C$ asiatica. $^{20}$

Dampak dari salah penggunaan tanaman obat atau pemalsuan adalah pengaruh yang berbeda terhadap penyakit yang dituju atau bahkan tidak ada pengaruh, atau dapat saling melengkapi. ${ }^{19}$ Oleh karena itu untuk mendapatkan bahan baku $C$. asiatica yang standard, maka perlu adanya data autentikasi makroskopis, mikroskopis, dan profil kimia dari jenis-jenis tumbuhan yang berpotensi sebagai adulteran dari $C$. asiatica, yaitu $H$. verticillata dan $M$. emarginata.

Tujuan dari penelitian ini adalah melakukan autentikasi dan membandingkan karakter makroskopis, mikroskopis, dan profil kimia dari C. asiatica, $H$. verticillata, dan M. emarginata. Selain itu, dilakukan juga penetapan kadar asiatikosida yang merupakan senyawa penanda $C$. asiatica.

\section{METODE}

Penelitian ini dilakukan di dua tempat, yaitu di lapangan dan di laboratorium, untuk di lapangan dilakukan secara eksploratif-kualitatif sedangkan di laboratorium dilakukan pengamatan (observasi) secara kualitatif dan kuantitatif.

Pengambilan sampel penelitian dilakukan pada tiga lokasi, yaitu Bogor (Jawa Barat, Tawangmangu (Jawa Tengah, dan Malang (Jawa Timur). Ketiga lokasi tersebut merupakan area budidaya dari ketiga jenis tanaman. Pelaksanaan pengamatan dilakukan di laboratorium Sistematika Tumbuhan, Galenika, dan 
Instrumentasi Balai Besar Penelitian dan Pengembangan Tanaman Obat dan Obat Tradisional (B2P2TOOT) Tawangmangu selama 8 bulan dari bulan FebruariSeptember 2017.

\section{Alat dan bahan}

Peralatan dalam pengamatan karakter mikroskopis menggunakan slide glass, cover glass, gelas ukur, gelas petri, pipet tetes, botol fiksasi, mikroskop, hotplate, mikrotom, Munsell Color Charts. Profil senyawa kimia dilakukan dengan menggunakan Kromatografi Lapis Tipis densitometer Linomat 5, scanner dan visualizer CAMAG.

Bahan yang dipergunakan dalam penelitian ini, antara lain spesimen tanaman C. asiatica, $H$. verticillata, dan $M$. emarginata berupa, simplisia, serbuk, dan tanaman hidup yang telah dideterminasi di B2P2TOOT, Tawangmangu. Pada pengamatan makroskopis dan mikroskopis sampel yang digunakan berasal dari 3 lokasi (Jawa Barat, Jawa Tengah, dan Jawa Timur), sedangkan sampel untuk profil kimia hanya berasal dari 1 lokasi (Jawa Tengah). Spesimen herbarium telah teridentifikasi oleh Peneliti B2P2TOOT dan tersimpan di Herbarium Tawangmanguense, B2P2TOOT. Selain itu, bahan adalah metanol pa, etanol pa, dan kloroform pa dari Merck, serta akuabides (Ikaphamapindo) dan reagen Liebermann-Burchard.

\section{Prosedur kerja}

\section{Cara pengumpulan data}

Pengumpulan data karakter makroskopis dilakukan di lapangan dengan menggunakan instrumen berupa form isian pengamatan karakter makroskopis, dan di laboratorium menggunakan form pencatatan pengamatan karakter mikroskopis. Untuk pengumpulan data profil kimia menggunakan instrumen TLC visualizer.

\section{Penentuan profil senyawa kimia dengan metode Kromatografi Lapis Tipis (KLT)}

Profil senyawa kimia dilakukan menggunakan metode KLT pada plat silika $\mathrm{GF}_{254}$. Masing-masing sampel ditimbang sebanyak $100 \mathrm{mg}$, dilarutkan dengan etanol $10 \mathrm{~mL}$, dan dikocok dengan sonikator. Filtrat dipisahkan dengan menggunakan sentrifuge. Masing-masing filtrat sampel ditotolkan sebanyak $2 \mu \mathrm{L}$ dengan alat Linomat 5 pada plat silika $\mathrm{GF}_{254}$, dilanjutkan dengan elusi menggunakan kloroform: metanol:air (65:25:4) hingga batas. Selanjutnya hasil elusi disemprot dengan reagen penampak bercak seperti reagen Liebermann-Burchard dan dianalisis lebih lanjut, difoto dengan visualizer pada sinar tampak dan UV $366 \mathrm{~nm}$.

\section{Penetapan kadar senyawa asiatikosida}

Prosedur penetapan kadar asiatikosida merujuk pada penelitian Pramono (2004) dengan sedikit modifikasi. Larutan baku asiatikosida dengan kadar $0,15 \mu \mathrm{g} / \mu \mathrm{L}$ dalam etanol, ditotolkan menggunakan syringe dengan volume $1,2,3,4$ dan $5 \mu \mathrm{L}$ pada plat silika gel $\mathrm{GF}_{254}$. Kemudian dilanjutkan dengan penotolan larutan sampel pengujian masing-masing sebanyak $15 \mu \mathrm{L}^{2}$

Sampel pengujian dipersiapkan dengan menimbang $100 \mathrm{mg}$ serbuk dan ditempatkan pada botol laboratorium yang berbeda, kemudian ditambahkan $10 \mathrm{~mL}$ etanol pa. Selanjutnya, dilakukan homogenasi menggunakan ultrasonikator selama 15 menit tanpa perubahan suhu dan dienapkan semalam. Sampel yang sudah terenap diambil sebanyak $2 \mathrm{~mL}$ kemudian diuapkan di oven pada suhu $40^{\circ} \mathrm{C}$ hingga pelarut menguap. Setelah kering, berikutnya ekstrak yang dihasilkan dilarutkan dalam $4 \mathrm{~mL}$ metanol pa, kemudian dilakukan homogenasi kembali selama 15 menit menggunakan ultrasonikator tanpa perubahan suhu. Sampel pengujian siap untuk digunakan.

Pengembangan sampel sama dengan penentuan profil senyawa kimia yaitu dilakukan dalam campuran fase gerak kloroform : metanol : air (65:5:4) hingga 0,5 $\mathrm{cm}$ dari batas akhir. Selanjutnya, dilakukan penyemprotan menggunakan reaksi penampak bercak Liebermann-Burchard, dipanaskan pada suhu $100^{\circ} \mathrm{C}$ selama 10 menit. Luas area dan nilai $\mathrm{Rf}$ masing- 
masing bercak ditentukan pada panjang gelombang optimum asiatikosida, yaitu 510 $\mathrm{nm}$ menggunakan scanner. Bercak asiatikosida standar dianalisis lineritasnya, sehingga selanjutnya kadar asiatikosida sampel dapat ditetapkan melalui persamaan yang diperoleh. Plat didokumentasikan dengan visualizer pada sinar tampak dan UV $366 \mathrm{~nm}$ agar dapat diperoleh kromatogramnya.

\section{HASIL DAN PEMBAHASAN}

\section{Pengamatan makroskopis}

Hasil pengelompokkan dengan menggunakan IBM SPSS Ver. 22 (Gambar 1), terlihat jelas secara morfologi kelompok C. asiatica berada satu cluster utama dengan $M$. emarginata, sedangkan kelompok $H$. verticillata berada pada cluster lainnya. Hal tersebut didukung bahwa secara morfologi bentuk daun cluster $C$. asiatica-M. emarginata berbentuk ginjal, sedangkan bentuk daun cluster $H$. verticillata berbentuk orbicular atau bundar (Gambar 2).

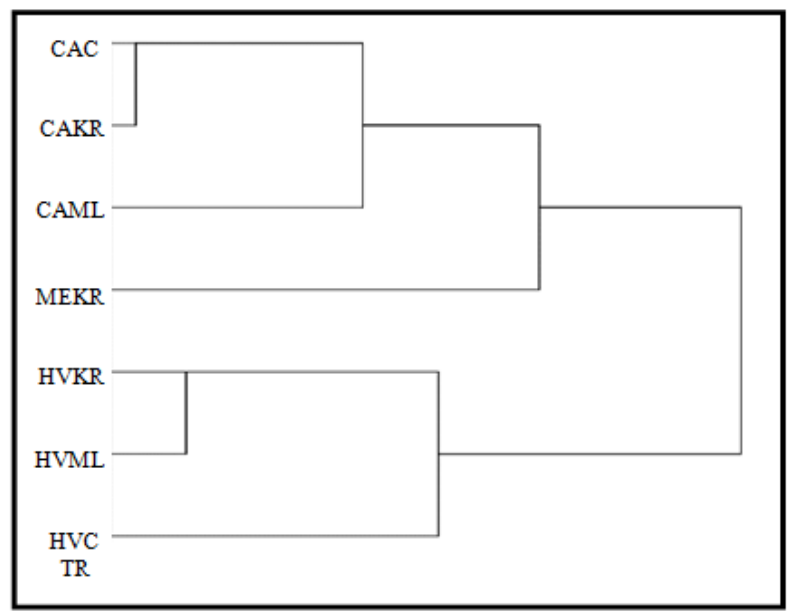

Gambar 1. Clustering spesies berdasarkan kemiripan karakter (keterangan: CACTR: $\boldsymbol{C}$. asiatica Citeureup, CAKRA: $C$. asiatica

Karanganyar, CAMLG: $C$. asiatica Malang, MEKRA: $M$. emarginata Citeureup, HVKRA: $\boldsymbol{H}$. verticillata Karanganyar, HVMLG: $H$. verticillata Malang, HVCTR: $\boldsymbol{H}$. verticillata Citeureup)

Secara kualitatif, karakter bentuk daun dapat dijadikan pembeda sangat jelas antara $H$. verticillata dengan cluster $C$. asiatica-M. emarginata. Di lain hal, terlihat jelas dalam cluster utama C. asiatica-M. emarginata, terdapat pemisahan cluster antara kelompok $C$. asiatica (dari 3 daerah) tersendiri dengan $M$. emarginata. Hal tersebut didukung dengan adanya perbedaan pada bentuk ujung daun, tepi daun, warna daun, warna stolon, panjang stolon, panjang tangkai daun, serta ukuran helaian daun (Gambar 2). Dengan demikian secara kualitatif bentuk ujung daun dan tepi daun jelas dapat dijadikan sebagai karaker pembeda yang kuat.

Hasil pengamatan karakter kualitatif menunjukkan bentuk morfologi yang berbeda antara $C$. asiatica dengan dua jenis potensi adulterannya, yaitu $H$. verticillata dan M. emarginata. Bentuk daun C. asiatica merupakan bentuk ginjal, sedangkan $H$. verticillata berbentuk orbicular. Selain itu, $M$. emarginata berbentuk ginjal namun berbeda pada bentuk ujung daun yang seringkali membelah (emarginate) yang tidak ditemui pada $C$. asiatica (Gambar 2).

Hasil pengamatan secara kualitatif terhadap simplisia ketiga jenis tumbuhan subjek penelitian menunjukkan bahwa simplisia $C$. asiatica lebih padat dibandingkan simplisia $H$. verticillata dan $M$. emarginata. Selain itu, terlihat jelas daun $C$. asiatica masih berbentuk bergerigi, berbentuk seperti ginjal, tetapi sering kali terlipat atau mengerut, warna daun hijau kekuningan, tekstur daun kasar serta agak tebal, memiliki bau yang tidak terlalu tajam, dan warna stolon coklat gelap. Di lain hal, simplisia $H$. verticillata memiliki daun berbentuk seperti perisai (peltate), tepi daun bulat beringgit, warna daun hijau, tekstur daun halus dan tipis, memiliki bau yang sedikit tajam, serta warna stolon putih. $M$. emarginata memiliki daun yang menggulung dan mengerut, berwarna coklat, tekstur daun kasar, memiliki bau yang tidak terlalu tajam, dan warna stolon coklat muda. Warna serbuk dari ketiga jenis tersebut masing-masing adalah $C$. asiatica berwarna kuning kecoklatan (5Y.5/4), $H$. verticillata berwarna hijau kekuningan (5GY.7/2), dan $M$. emarginata berwarna hijau kekuningan (2.5GY.5/2) (Gambar 3). 


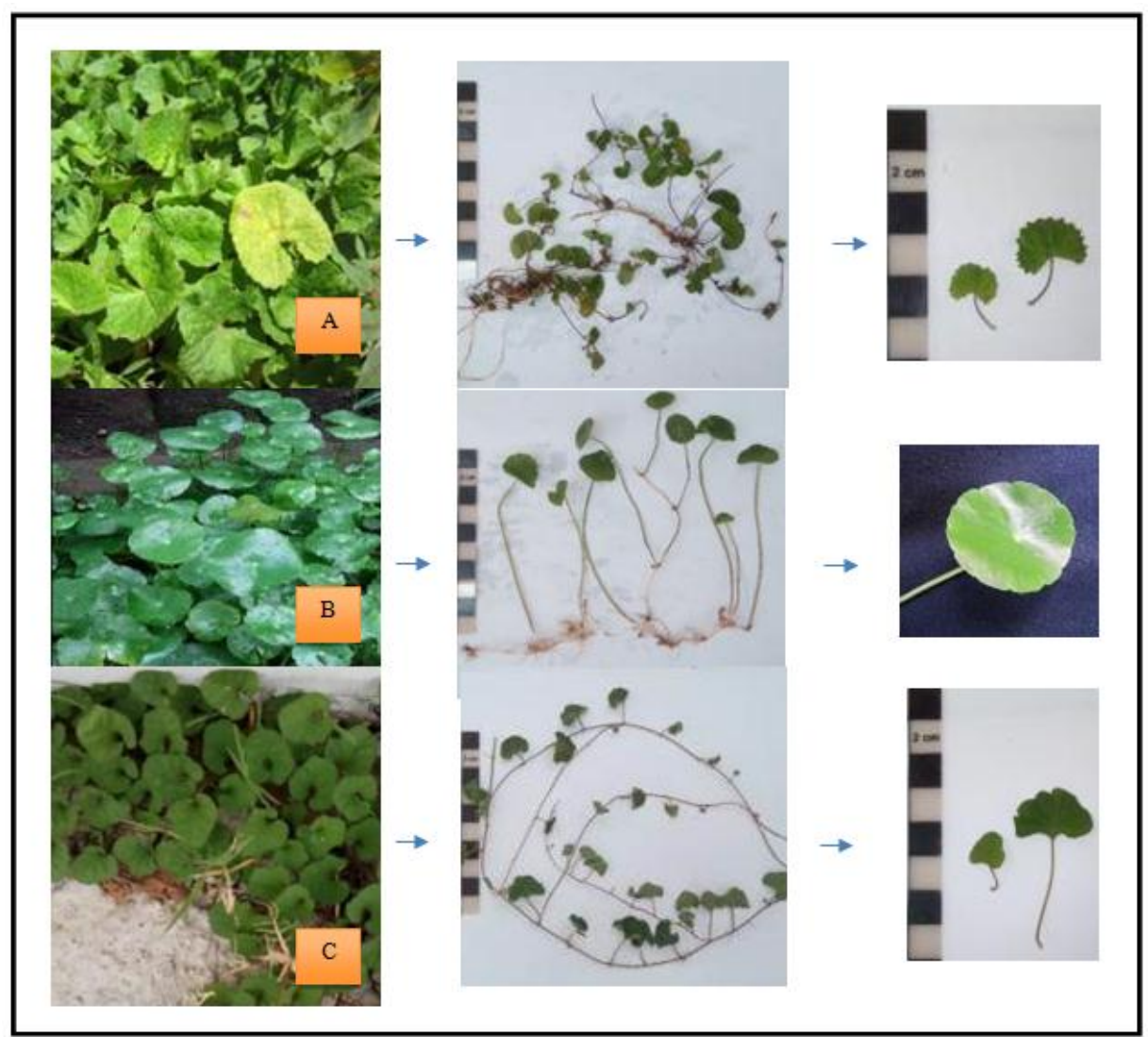

Gambar 2. Perbandingan karakter tiga spesies tumbuhan berdasarkan habitus tumbuhan dan morfologi daun (keterangan: A: Centella asiatica, B: Hydrocotyle verticillata,dan C: Merremia emarginata)

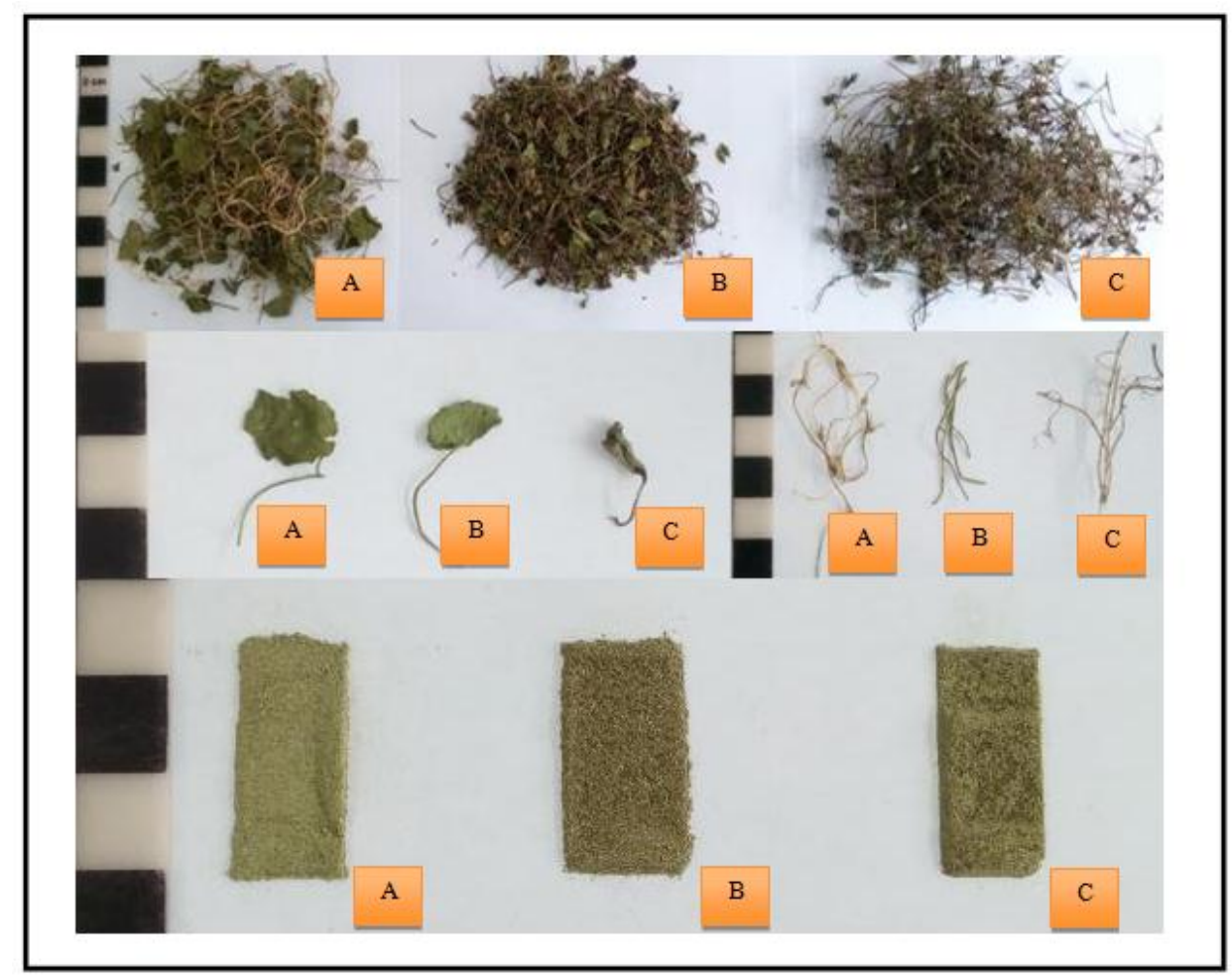

Gambar 3. Perbandingan karakter simplisia dan serbuk tiga spesies tumbuhan (keterangan: A: Hydrocotyle verticillata, B: Centella asiatica,dan C: Merremia emarginata). 
Tabel 1. Perbandingan karakter mikroskopik, simplisia, dan serbuk Centella asiatica, Hydrocotyle verticillata, dan Merremia emarginata berdasarkan dokumentasi fotografi.

\begin{tabular}{|c|c|c|c|c|}
\hline No. & Karakter & C. asiatica & H. verticillata & M. emarginata \\
\hline 1 & Stolon & & & \\
\hline 2 & Tangkai daun & & & \\
\hline 3 & Daun & $100 \mu \mathrm{m}$ & & \\
\hline 4. & Stomata & & & \\
\hline & & Tipe Anisositik & Tipe Parasitik & Tipe Parasitik \\
\hline 5. & Polen & & & \\
\hline
\end{tabular}

\section{Pengamatan mikroskopis}

Berdasarkan Tabel 1. secara kualitatif morfologi penampang melintang stolon dari tiga jenis tumbuhan yang berpotensi menjadi adulteran sangat berbeda. Perbedaan yang sangat mencolok adalah pada $M$. emarginata meskipun memiliki bentuk penampang yang hampir sama dengan $C$. asiatica, namun dapat terlihat bahwa pada $M$. emarginata tidak memiliki berkas pembuluh yang tersusun teratur seperti $C$. asiatica dan $H$. verticillata membentuk berkas, tetapi letak sel xylem pada penampang $M$. emarginata berada mengelilingi membentuk lingkaran dan sel floem terdiri atas 1-2 sel besar berada di atas sel xylem. Selain itu, pada $M$. emarginata terlihat memiliki trikom uniseluler pada bagian stolon. Di lain hal, perbedaan anatomi melintang stolon $C$. asiatica dan $H$. verticillata terlihat dengan perbedaan bentuk penampang stolon $C$. asiatica yang berbentuk lingkaran, sedangkan pada $H$. verticillata berbentuk lingkaran yang tepinya bergelombang. Namun, hal tersebut tidak konsisten pada bentuk stolon $C$. asiatica perwakilan dari daerah Malang, yaitu berbentuk lingkaran dengan lekukan yang cukup jelas dan mirip dengan bentuk penampang melintang tangkai daun $H$. verticillata perwakilan dari Karanganyar, tetapi kedua penampang tersebut dapat dibedakan dengan letak xylem dan floem pada berkas pembuluh, yaitu pada stolon $C$. asiatica letak sel xylem terpisah jelas dengan sel floem, sedangkan pada stolon $H$. verticillata letak xylem dikelilingi oleh sel floem.

Perbedaan karakter $C$. asiatica dengan dua jenis potensi adulteran lainnya adalah jelas terlihat adanya lubang di tengah 
penampang melintang tangkai daun $C$. asiatica, sedangkan pada tangkai daun $H$. verticillata dan $M$. emarginata masih terdapat sel parenkim bahkan berkas pembuluh pada $M$. emarginata. Dari keseluruhan sampel perwakilan dari Citeureup, Malang, dan Karanganyar, tidak terlihat perbedaan karakter bentuk dari $C$. asiatica, sedangkan pada $H$. verticillata perwakilan dari Citeureup terdapat perbedaan adanya berkas pembuluh di tengah penampang melintang dibandingkan dengan $H$. verticillata perwakilan dari dua daerah lainnya. Selain itu, dari karakter adanya trikom, hanya $H$. verticillata yang tidak memiliki trikom pada penampang melintang tangkai daun, sedangkan pada $C$. asiatica terdapat trikom yang tersusun dari dua sel (biseluler) yang berbeda dengan trikom tangkai daun $M$. emarginata yang tersusun atas satu sel (uniseluler).

Perbedaan karakter lain $C$. asiatica dengan dua jenis potensi adulteran lainnya adalah pada bentuk penampang melintang tulang daun, yaitu bentuk irisan melintang tangkai daun $C$. asiatica jelas memiliki bagian melebar pada bagian permukaan bawah daun yang dominan diisi oleh sel parenkim berbeda dengan bentuk irisan melintang tulang daun $H$. verticillata yang rata pada kedua sisi permukaan. Di lain hal, perbedaan karakter antara $C$. asiatica dan $M$. emarginata adalah bentuk berkas pembuluh $C$. asiatica berbentuk lingkaran dan xylem terletak pada bagian atas dan floem dibawah, sedangkan berkas pembuluh $M$. emarginata berbentuk memanjang dan xylem terletak dikelilingi oleh sel floem. Selain itu, pada bagian atas permukaan daun $M$. emarginata terdapat 3 lapisan sel kolenkim yang menonjol, sedangkan pada $C$. asiatica sel kolenkim berjumlah 2 lapisan dan tidak menonjol ke permukaan.

Centella asiatica memiliki tipe stomata anisosit. Tipe anisosit sel penutup dikelilingi oleh tiga sel tetangga yang tidak sama ukurannya. $^{22}$ Stomata yang dimiliki $H$. verticillata Thunb. dan $M$. emarginata merupakan tipe parasitik, yaitu tipe sel penutup yang didampingi oleh satu sel tetangga atau lebih dengan sumbu panjang sel tetangga sejajar dengan sumbul sel penutup serta celah. ${ }^{22}$ Di lain hal, tipe dari $C$. asiatica dan $H$. verticillata adalah monad, namun dari tipe aperture kedua jenis tersebut terdapat perbedaan, yaitu tipe aperture colpate pada $C$. asiatica, dan tipe aperture colporate pada $H$. verticillata.

\section{Penentuan profil senyawa kimia dengan metode Kromatografi Lapis Tipis (KLT)}

Penentuan profil senyawa kimia dilakukan dengan metode KLT, karena KLT diketahui merupakan salah satu metode yang efektif diaplikasikan dalam kontrol kualitas tanaman obat, termasuk profiling atau penyidik jari komponen kimia dari suatu ekstrak serta analisis kuantitatif senyawa penanda dalam herbal. Salah satu kelebihan dari metode KLT adalah sederhana, terjangkau, mudah diadaptasikan ke berbagai prosedur pemisahan dan digunakan hampir diseluruh laboratorium didunia sehingga dapat distandarisasi. ${ }^{23}$ Sidik jari berbasis kromatografi atau profiling dapat menunjukkan perbedaan ataupun kesamaan diantara sampel yang beragam, autentikasi dan identifikasi herbal atau tanaman obat tradisional.

Profil senyawa kimia dilakukan dengan penambahan reagen penampak bercak Lieberman-burchadad, yaitu jenis reagen yang digunakan untuk mendeteksi keberadaan senyawa terpenoid. Reaksi positif warna merah menunjukkan keberadaan senyawa triterpenoid, sedangkan warna biru kehijauan sebagai senyawa steroid. $^{24}$ Beberapa penelitian mengungkapkan bahwa senyawa bioaktif yang utama yang terkandung dalam $C$. asiatica merupakan golongan senyawa triterpenoid, seperti asam asiatik, asam madekasik, asiatikosida dan madekosida. Triterpenoid juga telah umum difungsikan sebagai komponen biomarker dari C. Asiatica. ${ }^{25,26}$ Oleh karena itu, senyawa triterpenoid dipilih sebagai parameter penetapan profil senyawa kimia dari ketiga sampel tersebut.

Kromatogram hasil penetapan profil 
senyawa kimia yang diamati pada UV 366 $\mathrm{nm}$ menunjukkan terdapat perbedaan jumlah senyawa dalam $C$. asiatica, $H$. verticillata dan $M$. emarginata. Tabel 2 menunjukkan bahwa komponen senyawa dalam $C$. asiatica jauh lebih banyak dibandingkan kedua sampel lainnya, yaitu terdeteksi terdapat 15 spot senyawa. Disamping itu, kromatogram tersebut menginfokan bahwa $C$. asiatica lebih banyak mengandung senyawa steroid dibandingkan $H$. verticillata dan $M$. emarginata. Hal ini ditunjukkan oleh lebih banyaknya jumlah spot dengan fluoresensi berwarna biru-kehijauan pada UV $366 \mathrm{~nm}$ setelah penambahan pereaksi Libermann burchard. Fluoresensi warna merah pada sampel $H$. verticillata dan $M$. emarginata menunjukkan keberadaan senyawa triterpenoid.

Perbedaan tersebut menunjukkan bahwa ketiga sampel tersebut merupakan tiga spesies sampel yang berbeda, karena profil kromatogram yang dihasilkan oleh ketiga spesies sampel tersebut memiliki perbedaan yang bermakna. Spesies tumbuhan yang berbeda tentu akan memiliki profil senyawa kimia yang berbeda, hal ini terkait dengan faktor genetik dari masing-masing spesies.

Tabel 2. Nilai Rf setelah penambahan pereaksi Lieberman-burchad pada UV $366 \mathbf{~ n m}$

\begin{tabular}{|c|c|c|c|}
\hline Nilai Rf & C. asiatica & H. verticillata & M. emarginata \\
\hline 0,03 & $\mathrm{v}$ & - & - \\
\hline 0,08 & $\mathrm{v}$ & $\mathrm{v}$ & $\mathrm{v}$ \\
\hline 0,12 & $\mathrm{v}$ & $\mathrm{v}$ & $\mathrm{v}$ \\
\hline 0,17 & $\mathrm{v}$ & $\mathrm{v}$ & $\mathrm{v}$ \\
\hline 0,22 & $\mathrm{v}$ & - & - \\
\hline 0,28 & - & $\mathrm{v}$ & - \\
\hline 0,32 & $\mathrm{v}$ & - & - \\
\hline 0,35 & - & - & $\mathrm{v}$ \\
\hline 0,42 & - & $\mathrm{v}$ & - \\
\hline 0,52 & $\mathrm{v}$ & $\mathrm{v}$ & $\mathrm{v}$ \\
\hline 0,60 & $\mathrm{v}$ & $\mathrm{v}$ & - \\
\hline 0,65 & $\mathrm{v}$ & - & - \\
\hline 0,69 & $\mathrm{v}$ & $\mathrm{v}$ & $\mathrm{v}$ \\
\hline 0,74 & $\mathrm{v}$ & - & - \\
\hline 0,77 & $\mathrm{v}$ & - & - \\
\hline 0,78 & $\mathrm{v}$ & - & - \\
\hline 0,83 & $\mathrm{v}$ & $\mathrm{v}$ & $\mathrm{v}$ \\
\hline 0,90 & $\mathrm{v}$ & $\mathrm{v}$ & $\mathrm{v}$ \\
\hline Total bercak & 15 & 10 & 8 \\
\hline
\end{tabular}

Keterangan

v : Terdeteksi

- : Tidak terdeteksi 


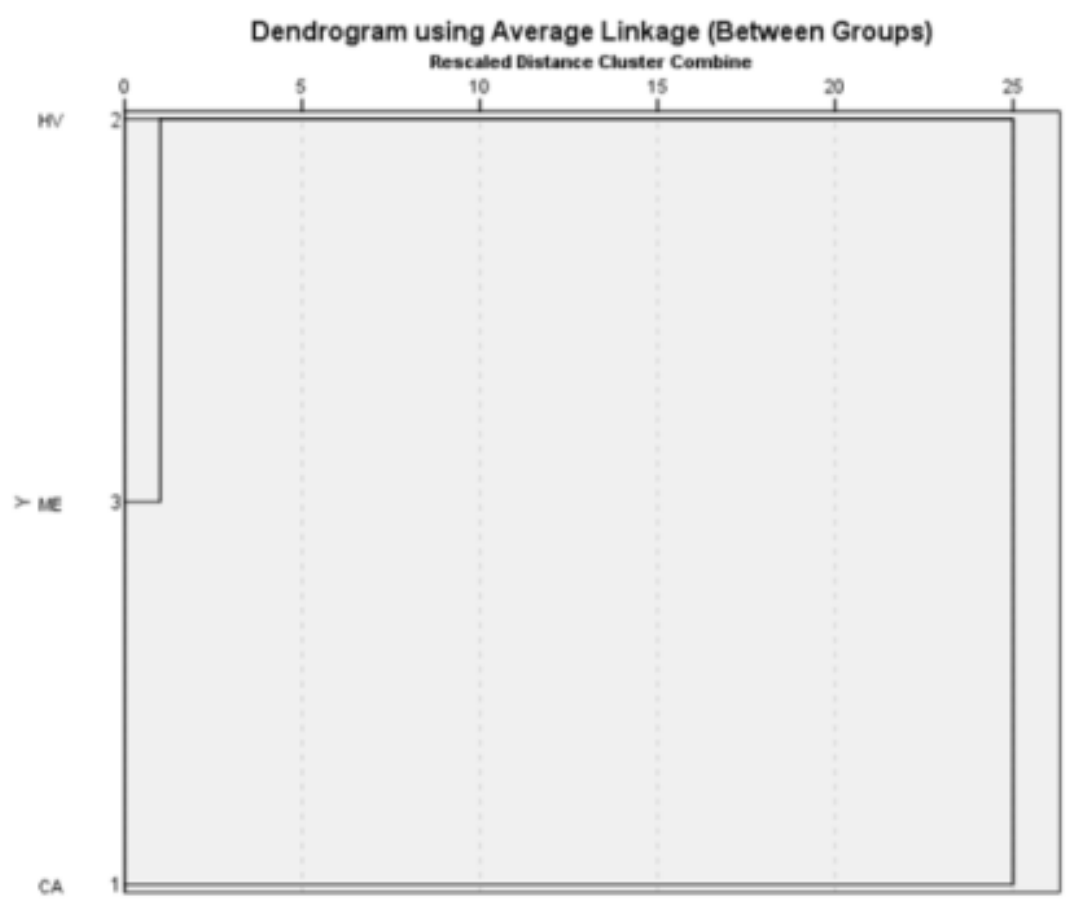

\section{Gambar 5. Analisis cluster hasil profiling senyawa triterpenoid dan steroid}

Faktor genetik suatu spesies berpengaruh pada proses biosintesis yang terjadi didalam sel, dimana salah satu produk dari biosintesis tersebut adalah senyawa metabolit sekunder. ${ }^{27-29}$

Berikutnya data Rf yang diperoleh pada penentuan profil senyawa kimia dilakukan analisis cluster menggunakan software SPSS (Gambar 4). Dendogram tersebut menunjukkan tingkat kemiripan antara spesies $C$. asiatica dengan kedua spesies lain, $H$. verticillata dan $M$. Emarginata sangat kecil. Hal ini tampak pada besarnya skala perbedaan antara $\mathrm{C}$. asiatica dengan kedua spesies lainnya. Akan tetapi, spesies $H$. verticillata dan $M$. Emarginata diketahui memiliki tingkat kemiripan yang cukup tinggi, sehingga dalam dendogram kedua spesies tersebut dikelompokkan menjadi satu cluster dengan skala perbedaan yang kecil.

Berdasarkan hasil penelitian ini ditunjukkan bahwa metode KLT merupakan metode yang efektif dan efisien untuk mengidentifikasi perbedaan antara $C$. asiatica, $H$. verticillata dan $M$. Emarginata. Hal ini sesuai dengan pendapat Renato ${ }^{23}$ bahwa sidik jari kimia atau profil secara kromatografi dapat digunakan untuk menunjukkan persamaan ataupun perbedaan diantara variasi sampel, selanjutnya dapat mendeteksi autentifikasi dan identitas dari sampel bahan baku obat termasuk tumbuhan.

\section{Penetapan kadar Asiatikosida}

Biomarker atau senyawa penanda utama bagi $C$. asiatica adalah golongan senyawa triterpenoid dan steroid, karena golongan senyawa tersebut merupakan komponen utama penyusun metabolit sekunder $C$. asiatica. Beberapa senyawa spesifik yang terdapat dalam $C$. asiatica dan memegang peran utama dalam aktivitas bioaktifnya, antara lain asam asiatik, asam madekasik dan asiatikosida. ${ }^{25,30}$ Farmakope Herbal Indonesia th 2008, menyatakan senyawa asiatikosida pada $C$. asiatica berperan sebagai biomarker atau senyawa penanda utama dalam uji kontrol kualitas herba pegagan sebagai tanaman obat. $^{31}$ Asiatikosida termasuk senyawa golongan steroid, sehingga perlu dilakukan penambahan reaksi penampak bercak sebelum tahapan analisis. Pereaksi penampak bercak yang digunakan adalah Liebermann-Burchard. Oleh karena itu, 
pada penelitian ini dilakukan penentuan kadar asiatikosida sebagai pembeda spesifik antara $C$. asiatica dan kedua sampel lainnya.

Hasil analisa kromatogram tersebut diperoleh kadar asiatikosida di ketiga jenis sampel seperti tercantum pada Tabel 3.Rerata kadar asiatikosida dalam sampel $C$. asiatica yang berasal dari daerah Jawa Tengah adalah sebesar 0,49\%, sedangkan pada $H$. verticillata dan $M$. emarginata tidak terdeteksi adanya kandungan asiatikosida. Asiatikosida merupakan komponen bioaktif utama dan biomarker padaC. asiatica. Berdasarkan hasil penetapan kadar asiatikosida tersebut dapat disimpulkan bahwa secara kimiawi $H$. verticillata dan $M$. emarginata adalah spesies yang berbeda dengan $C$. asiatica.

Kromatogram yang dihasilkan pada penetapan kadar senyawa asiatikosida (Gambar 6) menunjukkan terdapat spot dengan nilai $\mathrm{Rf}$ asiatikosida $(0,32)$, yaitu $\mathrm{Rf}$
0,28 pada $H$. verticillata dan $\operatorname{Rf} 0,35$ pada $M$. emarginata. Apabila dibandingkan dengan standar asiatikosida, kedua komponen pada $\mathrm{Rf}$ tersebut tidak terdeteksi besaran luas areanya sehingga kadar asiatikosidanya pun tidak dapat terdekteksi. Sehingga dapat dipastikan bahwa kedua senyawa tersebut bukan asiatikosida, namun memiliki tingkat kepolaran yang hampir sama dengan asiatikosida. Disamping itu, senyawa yang diduga memiliki tingkat kepolaran yang hampir sama dengan asiatikodisida tersebut, juga terdeteksi sebagai golongan senyawa steroid. Hal ini ditunjukkan oleh hasil positif berwarna biru kehijauan saat dikenakan reagen Liebermann-Burchard. Akan tetapi, untuk hasil yang lebih pasti perlu dilakukan analisis lain, khususnya terhadap kedua komponen tersebut sehingga dapat dipastikan bahwa kedua komponen tersebut bukan senyawa asiatikosida.

Tabel 3. Kadar asiatikosida C. asiatica, H. verticillata, dan M. emarginata

\begin{tabular}{llccc}
\hline No & \multicolumn{1}{c}{ Sampel } & Rf & $\begin{array}{c}\text { Rerata luas area } \\
(\mathrm{AU})\end{array}$ & $\begin{array}{c}\text { Rerata kadar asiatikosida } \\
(\%)\end{array}$ \\
\hline 1 & Centella asiatica & 0,32 & 184,64 & 0,49 \\
2 & Hydrocotyle verticillata & - & 0 & 0 \\
3 & Merremia emarginata & - & 0 & 0 \\
\hline
\end{tabular}

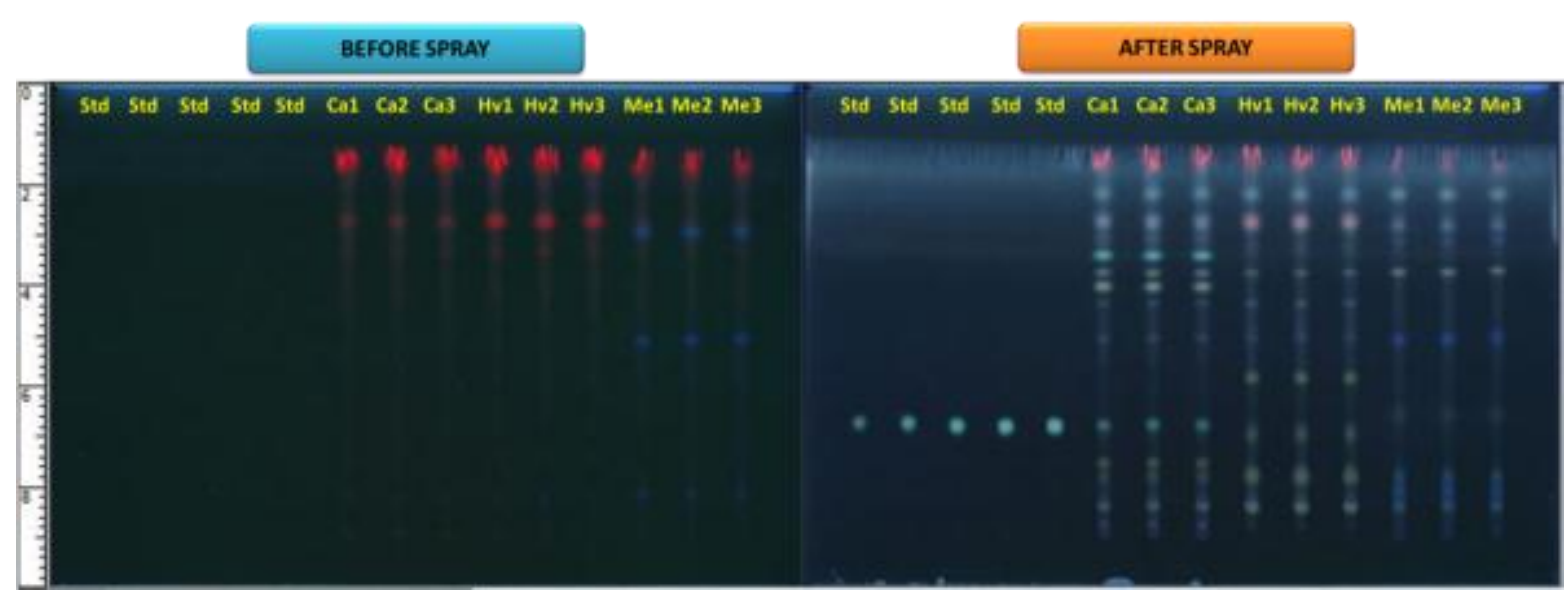

Gambar 6. Profil KLT sebelum dan setelah pereaksi penampak bercak pada UV 366 nm 


\section{KESIMPULAN}

Karakter pembeda yang unik dan mudah secara makroskopis antara Centella asiatica dengan spesies potensi adulteran Hydrocotyle verticillata adalah bentuk daun, sedangkan $C$. asiatica dengan Merremia emarginata adalah karakter tepi daun dan bentuk ujung daun. Selain itu, karakter bentuk daun simplisia antara $C$. asiatica dan $H$. verticillata dapat dijadikan pembeda yang jelas. Karakter pembeda untuk simplisia berupa daun dan simplisia berupa serbuk dapat dilakukan secara makroskopis dengan melihat perbedaan dari bentuk daun kering dan warna serbuk. Selain itu, karakter anatomi dan fragmen serbuk yang dapat dijadikan pembeda antara $C$. asiatica dan $H$. verticillata adalah keberadaan empulur pada tangkai dan stolon, tipe stomata, dan adanya trikom. Begitu pula dengan profil senyawa kimia $C$. asiatica memiliki perbedaan yang signifikan dibandingkan $H$. verticillata dan $M$. emarginata. Oleh karena itu, berdasarkan analisis cluster $C$. asiatica berada pada cluster yang terpisah dari kedua sampel lainnya. Rerata kadar senyawa asiatikosida dalam sampel $C$. asiatica yang berasal dari Jawa Tengah adalah 0,49\%, sedangkan pada $H$. verticillata dan $M$. emarginata tidak dapat terdeteksi kadar asiatikosida. Dapat disimpulkan bahwa senyawa asiatikosida merupakan biomarker spesifik untuk identifikasi C. asiatica.

\section{SARAN}

Senyawa biomarker yang spesifik untuk C. asiatica adalah senyawa asiatikosida, sehingga untuk memastikan kebenaran tanaman $C$. asiatica melalui penentuan keberadaan baik secara kualitatif ataupun kuantitatif menggunakan LCMS.

\section{UCAPAN TERIMA KASIH}

Penulis mengucapkan terima kasih kepada Sekretariat Badan Litbangkes atas pendanaan penelitian, Drs. Slamet Wahyono, M.Sc., Apt. dan Dr. Ir. Yuli Widiyastuti, MP atas bimbingan teknis dalam penelitian ini.

\section{DAFTAR RUJUKAN}

1. Goltenboth F, Timotius K, Po Milan P, Margraf J, editors. Ecology of insular Southeast Asia: The Indonesian Archipelago. Amsterdam: Elsevier; 2006.

2. Elfahmi, Woerdenbag HJ, Kayser O. Jamu: Indonesian traditional herbal medicine towards rational phytopharmacological use. Journal of Herbal Medicine. 2014 June;2(4):51-73.

3. Suhendang E. Pengantar ilmu kehutanan. Bogor: IPB Press; 2002.

4. Backer, C. A. and Brink VB. Flora of Java (Spermatophyte only): vol.II. Groningen: N.V.P. Noordhoff; 1963.

5. Hargono D, Lastari P, Astuti Y, Van den Bergh MH. Centella asiatica (L.) Urb. [Internet]. PROSEA (Plant Resources of South-East Asia) Foundation. 1999; 190-4 [dikutip 10 November 2016]. . Tersedia pada: http://proseanet.org/prosea/eprosea detail.php?frt=\&id=68

6. Kriswiyanti E, Junitha IK, Sri Kentjonowati E, Darsini N, Setyawati I. Inventarisasi bahan obat tradisional di Kecamatan Kintamani, Kabupaten Bangli, Bali. Seminar Nasional HUT Kebun Raya Cibodas Ke-159. 2011; 108-12.

7. Due R. Etnobotani tumbuhan obat Suku Dayak Pesaguan dan implementasinya dalam pembuatan flash card biodiversitas. Universitas Tanjungpura; 2013;7-10.

8. Wulandari RA, Azrianingsih R. Etnobotani jamu gendong berdasarkan persepsi produsen jamu gendong di Desa Karangrejo, Kecamatan Kromengan, Kabupaten Malang. Biotropika. 2014;2(4):198-202.

9. Belwal T, Andola HC, Atanassova MS, Joshi B, Suyal R, Thakur S, et al. Gotu Kola (Centella asiatica). In: Nabavi SM, Silva AS, editor. Nonvitamin and nonmineral nutritional supplements. London: Elsevier Inc.; 2019;p. 265-75.

10. Omar N, Lokanathan Y, Mohd Razi ZR, Bt Haji Idrus R. The effects of Centella asiatica (L.) Urban on neural differentiation of human mesenchymal stem cells in vitro. BMC Complementary Alternative Medicine. 2019;19(1):1-15.

11. Wannasarit S, Puttarak P, Kaewkroek K, Wiwattanapatapee R. Strategies for improving healing of the gastric epithelium using oral solid dispersions loaded with 
pentacyclic triterpene-rich Centella extract. AAPS Pharmaceutical Science Technology. 2019;20(7):277.

12. Camacho-Alonso F, Torralba-Ruiz MR, García-Carrillo N, Lacal-Luján J, MartínezDíaz F, Sánchez-Siles M. Effects of topical applications of porcine acellular urinary bladder matrix and Centella asiatica extract on oral wound healing in a rat model. Clinical Oral Investigations. 2019;23(5):2083-95.

13. Harun NH, Septama AW, Wan Ahmad WAN, Suppian R. The potential of Centella asiatica (Linn.) Urban as an anti-microbial and immunomodulator agent: A Review . Natural Product Sciences. 2019;25(2):92.

14. Jin SG, Kim KS, Yousaf AM, Kim DW, Jang SW, Son MW, et al. Mechanical properties and in vivo healing evaluation of a novel Centella asiatica-loaded hydrocolloid wound dressing. International Journal of Pharmaceutics. 2015;490(12):240-7.

15. Mariska E, Sitorus TD, Rachman JA. Effect of Centella asiatica leaves on gastric ulcer in rats. Althea Medical Journal. 2015;2(1):114-8.

16. Gray NE, Harris CJ, Quinn JF, Soumyanath A. Centella asiatica modulates antioxidant and mitochondrial pathways and improves cognitive function in mice. $\mathrm{J}$ Ethnopharmacol. 2016;180:78-86.

17. Triyono A, Zulkarnain Z, Mana TA. Studi klinis ramuan jamu antihipertensi pada pasien hipertensi derajat I. Jurnal Kefarmasian Indonesia. 2018;8(1):17-25.

18. Triyono A, Ridha P, Ardianto D. Uji klinik khasiat sediaan rebusan ramuan jamu hipertensi dibanding seduhan jamu hipertensi (Clinical trial the efficacy of boiled hypertension herbs compared with steeped hypertension herbs). Jurnal Ilmu Kefarmasian Indonesia. 2018;16(1):78-85.

19. Upton R, Graff A, Jolliffe G, Länger R, Williamson E, editors American herbal pharmacopoeia: Botanical pharmacognosy. microscopic characterization of botanical medicines. Boca Raton: CRC Press;2011.

20. Mansur M. Merremia emarginata (Burm.f.) Hallier f. [Internet]. PROSEA (Plant
Resources of South-East Asia) Foundation. 2001 [dikutip 10 November 2016]. Tersedia pada: http://proseanet.org/ prosea/e-prosea_detail.php?frt=\&id=1191

21. Pramono S dan D. Ajiastuti. Standardisasi ekstrak herba pegagan (Centella asiatica. (L.). Urban) berdasarkan kadar asiatikosida secara KLT-densitometri densitometric method. Majalah Farmasi Indonesia. 2004;15(3):118-23.

22. Mulyani S. Anatomi tumbuhan. Yogyakarta: Kanisius; 2006.

23. Braz R, Wolf LG, Lopes GC, De JCP. Quality control and TLC profile data on selected plant species commonly found in the Brazilian market. Brazilian Journal of Pharmacognocy. 2012;22(5):1111-8.

24. Edeoga HO, Okwu DE, Mbaebie BO. Phytochemical constituents of some Nigerian medicinal plants. African Journal of Biotechnology. 2005;4(7):685-88.

25. Hashim P, Sidek H, Helan MHM, Sabery A, Palanisamy UD, Ilham M. Triterpene composition and bioactivities of Centella asiatica. Molecules. 2011;16(2):1310-22.

26. Bandara MS, Lee EL, Thomas JE. Gotu Kola (Centella asiatica L.); An underutilized herb. The Americas Journal of Plant Science and Biotechnology. 2011;5(2):20-31.

27. Kopka J, Fernie A, Weckwerth W, Gibon Y, Stitt M. Metabolite profiling in plant biology: Platforms and destinations. Genome Biology. 2004;5(6):109.

28. Kessler A, Kalske A. Plant Secondary Metabolite diversity and species interactions. Annual Review of Ecology, Evolution, and Systematics. 2018;49(1):115-38.

29. Fang C, Fernie AR, Luo J. Exploring the diversity of plant metabolism. trends in plant Science. 2019;24(1):83-98

30. Tdck D, Am A, Salim N, Ug C. Evaluation of Centella asiatica morphotypes for high yields of asiaticoside. Journal of Pharmacognosy and Phytochemistry. 2016;5(6):451-4.

31. Farmakope Herbal Indonesia. Jakarta: Departemen Kesehatan Republik Indonesia; 2008. 